\title{
Unwelcomed Civilization: Emily Brontë's Symbolic Anti-Patriarchy in Wuthering Heights
}

\author{
Moussa Pourya Asl \\ English Language and Literature Department \\ Azarbaijan Shahid Madani University of Tabriz \\ Tabriz, Iran \\ Ahad Mehrvand \\ Assistant Prof. of Literary Studies, \\ English Language and Literature Department \\ Azarbaijan Shahid Madani University of Tabriz, Iran
}

Received: 05-02-2014

doi:10.7575/aiac.ijclts.v.2n.2p.29
Accepted: 30-02- 2014

Published: 01-04-2014

URL: http://dx.doi.org/10.7575/aiac.ijclts.v.2n.2p.29

\begin{abstract}
This study aims to show how Emily Brontë's opposing attitude to civilization in Wuthering Heights reveals to a certain degree her unconscious opposition to authority and accordingly her obsession with the notion of a world in which the father figure is finally slain. The research approach adopted in this study is what is referred to as psychobiography or the Freudian psychoanalytic criticism. Freud's ideas have been employed due to the increasing shift to him in the recent decades, particularly in the discipline of psychobiography. The findings of this research underline that in Wuthering Heights, through Catherine's symbolic fall, not into heaven, but into hell, and through her strong feelings of nostalgia for a lost freedom and happiness, Emily Brontë calls into question the values of patriarchal culture and its code of conduct. The main conclusion to be drawn from this article is that whatever the benefits of civilization-which is intrinsically and necessarily patriarchal in nature-may be, the limitations imposed on its citizens are not at all welcomed.
\end{abstract}

Keywords: Emily Brontë; Wuthering Heights; Civilization; Patricide; Repression

\section{Introduction}

Since its publication, Wuthering Heights has been the subject of an extensive and often contradictory range of interpretations and criticisms. Recently a number of psychoanalytic studies of Wuthering Heights have drawn on certain concepts like repression, death, rebellion and religion. For instance, Margaret Homans in "Repression and Sublimation of Nature in Wuthering Heights" (1978), Kelly Hughes in "The Freedom of the Soulful Self: An Examination of the Tension Between the Self and Society Within Wuthering Heights" (2006), Laura Inman in "The Awful Event in Wuthering Heights" (2008), Linda Gold in "Catherine Earnshaw: Mother and Daughter" (1985) and Moussa Pourya Asl in "Recurring Patterns: Emily Brontë's Neurosis in Wuthering Heights"(2014), each takes a thread and follows the path to the ever difficult task of interpretation of the novel. However, few of these studies confidently emphasize on Emily Brontë's unconscious unresolved conflicts as the latent content operating behind the manifest content of Wuthering Heights.

In the present study, we have employed Freudian psychoanalysis to argue that a feeling of anti-patriarchy, projected in the form of rejection of civilization, seems to be the obsessional thought of the neurotic author of Wuthering Heights. This will be discussed by referring to a previous study by Moussa Pourya Asl (2014) which has concluded that Emily Brontë was a neurotic person whose unconscious obsessions are projected in Wuthering Heights (50).

The significance of this study lies in the fact that an analysis of the manifest elements of the novel will lead to the latent and unconscious detriments of its creator's psyche, and eventually to a closer interpretation of the text. It will demonstrate how the author's repressed impulses are projected and transferred onto the novel's characters, plot, imagery and structure. This analysis is significant in that it will generate and substantiate the idea that rejection of civilization and accordingly authority forms the core of Emily Brontë's novel.

\section{Literature Review}

Critical reception of Wuthering Heights in psychoanalytic field has increasingly risen and has given critics many diverse elements for interpretation. Researchers like Margaret Homans, Kelly Hughes and Moussa Pourya Asl have tended to concentrate on certain concepts like repression, death, rebellion, religion, etc. These critics have found many to talk about in these concepts, and were quick to explore the various meanings of the novel. 
2.1 Repression and Sublimation of Nature in Wuthering Heights

Margaret Homans, for instance, in her work "Repression and Sublimation of Nature in Wuthering Heights" (1978), opens a discussion on the significant issue of the function of repression and sublimation in Wuthering Heights. She contends that Emily "always seems to bend her vision away from nature", since Emily avoids the direct presentation of the natural context (9). She declares that such an absence of the literal nature necessarily signals the repression of the nature. According to Homans,

writing creates an order of priority. Ordinarily, a word presents itself as coming first to the reader, putting its referent in second place. The only way to preserve the priority of something is not to have it named, so that what is primary is just that which is left out of the text, and surely these omissions of descriptions of events in nature are significant holes. [....] Both Brontë and her Cathy avoid description of nature or of events in nature because there is no way to name nature without making it secondary. Primary nature neither needs to be nor can be referred to. (11)

Homans maintains that the repression of nature is also accompanied by a pattern of entrapment existing within the novel. She notes that the use of images like locked windows, "body as a trap for the soul", or "entrapment of one character by the will of another" indicates that the condition of "the narrative as a whole is some kind of entrapment", too (11). Later, Homans distinguishes two separate versions of nature in the novel, "the primal or literal, which is unseen or evaded, and the figurative, which thrives on the textual surface of the novel (12). That the "primal nature" is textually shunned in Wuthering Heights, Homans believes, is due to the fact that Emily finds language inadequate for representing nature or event in nature. Furthermore, based on Freudian concept of sublimation, Homans concludes that there might be "a psychic path in Brontë between nature and some primal force" (16). Therefore, nature functions as an "ideational representative" of something which is intrinsically unnamable and threatening. This threatening force is to be feared and whatever is associated with it is to be repressed. Thus, Homans comes to the point that Emily is "repressing, not nature, but what nature has come to represent" (16).

A notable feature of Homans' article, and arguably a weakness, is the idea that the novel, as a text, is considered to lack whatever is associated with the unconscious. Based on the Freudian proposition of the sublimation, Homans regards Wuthering Heights as an activity in which the repressed is re-repressed. This causes Homans to overlook a key Freudian belief that a work of art is necessarily a resurfacing of repressed desires in a displaced, distorted, and a condensed form. She claims, "it is not Brontë's but her fictional characters' repressions that have so disastrously returned" (18).

Homans' article, excellent as it is, fails to ask crucial questions at this point to express who is behind these fictional characters; what the goal of the creation of such characters is; whether the creator is a mentally healthy being; why she wrote a novel; and what it is that is truly being repressed. This is one of the lacunae we intend to address in our paper, by paying particular attention to the role of the creative writer in creating such a world of phantasy and also by analyzing the manifestations of such repressions within the novel.

\subsection{The Freedom of the Soulful Self: An Examination of the Tension between the Self and Society within Wuthering} Heights

In a thesis entitled "The Freedom of the Soulful Self: An Examination of the Tension Between the Self and Society Within Wuthering Heights" (2006), Kelly Hughes focuses on the conflicts that exist between the innate self against the socially approved self. Hughes' main assertion is that Emily advocates the point that true satisfaction will be solely acquired "through the individual's fulfillment of the innate desires of their soul, not through conformity to popular expectations" (3). She observes that Wuthering Heights is a metaphysical novel, in which the soulful connection between Heathcliff and Catherine happens "outside the restrictions of society, in the freedom of their soulful selves" (23). Hughes claims that Emily asserted that such a connection existed beyond death, and the body was regarded as a place of confinement and restriction on the soul. For instance, Hughes examines Catherine Earnshaw's death and concludes that through her death Emily advocated the belief that physical death and accordingly releasing of the soul would free the individual's soul "from the constraining societal binds" that the person was suffering from and would ultimately allow his or her soul the freedom it desired (22).

Hughes argues that such a common theme, which is reflected within all of Emily's literary works, emanates from her personal life. According to Hughes, the isolation of Emily's home, the tensions and expectations of Victorian society as well as the impositions of rules and regulations led her to develop an introverted personality who was always seeking for a way to free herself from such regulations (6).

Unlike Homans, who found nature repressed and shunned by Emily, Hughes declares that nature functioned as a releasing factor for Emily, asserting that,

although primarily an introvert within her house, Emily seemed to "come alive" when outside, particularly when exploring the moors surrounding her house. A close family friend describes Emily's relationship to the moors as, "Nowhere else was [Emily] so much herself, nowhere else so free..." (Gerin 35). For Emily, her experiences in nature were not simply an escape from the influence of her aunt[,] [t]her[e] were times when she was the most able to be herself. Nature allowed for Emily a means of releasing inhibitions and engaging with life freely. The freedom of being that Emily found in nature is one she began to take with her into her everyday life and is reflected within her literary works. (5-6) 
Hughes' thesis has been inspirational for us, since it helped us to develop the concept of anti-patriarchy to describe the ways Emily opposed the Victorian society and whatever rule is established by the father figure by a symbolic rejection of the civilization. Hughes sums up that Emily finds the solution to the conflicts between the self and the society through death, or sacrifice of some sort.

\subsection{Recurring Patterns: Emily Brontë's Neurosis in Wuthering Heights}

In his article "Recurring Patterns: Emily Brontë's Neurosis in Wuthering Heights" Moussa Pourya Asl takes a wider view of the interpretation of the novel. Based on Freudian perspectives, Pourya studies Emily Brontë's personal life and novel to conclude that Emily Brontë grew up as a neurotic person "to create imaginary worlds within which she would be able to respond to her secret wishes". According to him, Emily Brontë's oppressive father, the harsh regime of Clergy Daughter's School and the Victorian society's rigid definition of gender roles "created a rigorously oppressive milieu that ultimately led Emily Brontë to develop an overactive superego to suppress the desires forbidden by society" (49-50).

Pourya further goes on to draw attention to certain recurrent patterns of orphaned and abandoned children; a system of masters and servants; reincarnation of characters; infanticide and sadism and brother/sister selves, to name a few, to emphasize how certain ideas are compulsively repeated throughout the novel. Finally, he concludes that Emily Brontë suffered from obsessive compulsive disorder and in Wuthering Heights she found an unconscious outlet for the partial gratification of her repressed wishes (48-49).

\section{Discussion}

\subsection{Theoretical Background}

A Freudian reading of Wuthering Heights also confirms that hatred of father and rejection of authority form the core of Emily Brontë's novel. Throughout Wuthering Heights, she rebels against the unjust, inhumane restrictions of a society that condones gender discrimination, cruelty, female oppression and child abuse. She seems to be obsessed with the notion of a world in which male dominancy is replaced with female supremacy (Winniffrith, 1996, p. 23). Accordingly, she envisions a world in which the father figure is finally slain and knowledge of his death brings a curious sense of relief and release. Emily Brontë's opposing attitude to civilization reveals to a certain degree her unconscious opposition with authority.

In Freudian psychoanalysis, such a nonconformity emanates from the individual's repressed and latent desire for rebellion against father figure. However, unless one appreciates the Freudian concept of Oedipus complex and its subsequent consequences, one would not be able to understand the individual's unconscious impulse of patricide. Moreover, a brief study of Freudian theories, particularly those on female sexuality would be helpful to realize the reason behind Emily Brontë's rejection of patriarchy.

In his "Female Sexuality" (1931), Freud argues that in female development there is a process of transition from one phase to the other. He believes that female's sexual life, unlike that of male's, is normally divided into two significant phases. The first one has a masculine character, whereas the other one is specifically feminine (p. 4592). During the masculine phase, which Freud calls it the pre-Oedipus phase, the female child's love-object is her mother. Freud argues that the primary conditions for a choice of objects are the same for all children. Therefore, the little girl, like a male child, initially develops an intense attachment to the mother and a simultaneous hatred for the father as a rival. He maintains that in this phase "a little girl's father is not much else for her than a troublesome rival, although her hostility towards him never reaches the pitch which is characteristic of boys" (p. 4592). At the end of her development, the female child advances to the second phase. Accordingly, in this phase, the little girl becomes aware of her body and of the bodies of people around, particularly her parents. Discovering the physical differences between male and female, she finds out that the mother, like her, has no penis. Therefore, she is ready to transfer her sexual attachment to father and to participate in a competition with mother for sexual possession of father (p. 4591).

Freud's observations reveal that the female child's attachment to her father was built up upon an original relation to her mother. In his late theory on the feminine, Freud recognized the early and continuing dependence of the female child on her mother during the pre-Oedipal stage; in that "the woman's attachment to her father was particularly intense, [and] analysis showed that it had been preceded by a phase of exclusive attachment to her mother which had been equally intense and passionate" (p. 4591). To Freud, this phase possesses great importance in female sexual life since a number of women, according to him, "remain arrested in their original attachment to their mother and never achieve a true change-over towards men" (p. 4591).

Feeling attracted to her mother, the little girl longs for total possession of her. However, she recognizes her father as a rival and becomes frantically jealous of him. She fantasies about killing him so that the love-object, the mother, would be hers alone. Yet like a boy, the female child is also aware of the power of her father and she fears his response. According to Freud, the child ultimately deals with this fear by erecting defense mechanism, noticeably by repressing his/her thoughts. In spite of this, the child, still, unconsciously endeavors to gratify these repressed impulses through the process of displacement.

Ultimately, the child finds relief from the ambivalent emotional attitude towards his father by displacing his/her hostile and fearful feelings onto a substitute for his/her father. He maintains that the displacement, nonetheless, cannot "bring the conflict to an end [...] on the contrary, the conflict is resumed in relation to the object on to which the displacement has been made: the ambivalence is extended to it" (Freud, 1913, p. 2769). For instance, Freud argues that the child 
identifies father with strict authority in all forms, such as civilization. Therefore, the child's subsequent hostility to authority is associated with the Oedipal complex.

In this regard, Freud associates the civilization with the father figure. In his "Civilization and Its Discontents" (1930), he draws our attention to the conflict between instinctual impulses and social well-being. Like a father, the society is considered as an obstacle for the satisfaction of the individual's sexual desires. He argues that the first requisite of the civilization is the repression of the individual's libidinal impulses. According to him,

human life in common is only made possible when a majority comes together which is stronger than any separate individual and which remains united against all separate individuals. The power of this community is then set up as 'right' in opposition to the power of the individual, which is condemned as 'brute force'. This replacement of the power of the individual by the power of a community constitutes the decisive step of civilization. The essence of it lies in the fact that the members of the community restrict themselves in their possibilities of satisfaction, whereas the individual knew no such restrictions (p. 4492).

Freud continues to investigate the mutual relationship between women and civilization. He finds out that women adopt a hostile attitude towards civilization due to the fact that "civilization has become increasingly the business of men" (p. 4497). In this business, women find themselves forced into the background, since civilization confronts men with "ever more difficult tasks and compels them to carry out instinctual sublimation of which women are little capable" (p. 4497). As a result, women soon come into opposition to civilization.

To Freud, the hostility to civilization and any sorts of regulations and conventions is fundamentally linked with the inhibiting role of the father. As we have already seen, the child shifts and displaces an impulse from a threatening object-father-to a non-threatening one - civilization, for instance. In other words, viewed from the Freudian psychoanalysis, all rebellion is in essence a rejection of parental, especially paternal authority, which stems from the individual's Oedipal impulses.

\subsection{Symbolic anti-Patriarchy in Wuthering Heights}

The study of Emily Brontë's Wuthering Heights in the light of Freudian paradigm of female sexuality points to the fact that Emily Brontë did not make the transition from a girl to a normal woman. Indeed, she had a fixation on her mother and perceived her father as an obstacle and a rival for her mother's affection. Therefore, she became obsessed with the unconscious desire to rebel against the father figure. And finally the identification of her father with strict authority led Emily Brontë to revolt against any kinds of impositions on her. So, civilization became one of the safe substitutes upon which she displaced her unconscious desire of patricide.

Wuthering Heights, indeed, is a bitter parody of the patriarchal nature of culture that inflicts imprisonment and despair on individuals and ultimately leads to their discontent. Emily Brontë portrays Catherine's experience of a civilized, heavenly life in Thrushcross Grange as a fall, not from hell to heaven but from heaven to hell. Through Catherine's fall, Emily Brontë endeavors to depict the discontents inherent in civilization. More importantly, Catherine refutes the new civilized life, when she says, "heaven did not seem to be my home; and I broke my heart with weeping to come back to earth; and the angels were so angry that they flung me out, into the middle of the heath on the top of Wuthering Heights; where I woke sobbing for joy" (ch.ix, p. 63). The excerpt symbolically draws further attention to Emily Brontë's parody of civilization and its discontents. To this end, Emily Brontë compares the two families of Earnshaws and Lintons and their respective houses of Wuthering Heights and Thrushcross Grange.

Wuthering Heights is stationed in an exposure of stormy weather. Its residents are barely literate and they "appear to live tottering on the brink of barbarism" (Reed, 1989, p. 212). The Earnshaws seem primitive and possess only the basics of civilization. The inhabitants grow up as rebellious, uncultivated, free, and "as rude as savages" (ch.vi, p. 36). Heathcliff appears to be "wolfish" and Catherine wildly resists her father's taming influence.

Thrushcross Grange is a pole apart. Unlike Wuthering Heights, which "is being close to being naked or 'raw' [...] its floors uncarpeted, most of its inhabitants barely literate, even the meat on its shelves open to inspection-Thrushcross Grange is clothed and 'cooked', bookish, feeding on cakes and tea and negus" (Gubar, 1979, p. 389). They are civilized, refined and elegant. Emily Brontë juxtaposes the uncultivated heath of Wuthering Heights with the heavenly comfort and peace of Thrushcross Grange. Catherine's first glimpse of the life of the civilized Lintons, lightens in her mind the speculation that if Heathcliff and she were inside such aroom, "we should have thought ourselves in heaven!" (ch.vi, p.38).

Eventually, the civility of Thrushcross Grange attracts Catherine. She chooses to move there and thus puts on the clothes of civility proposed by the civilized Lintons family. She exchanges her freedom and savage rebellion in Wuthering Heights for civilized comformity in Thrushcross Grange. The influence of the gentry household permits Catherine to be "the young lady her father, Nelly, Hindley, and Hindley's wife Frances had tried to make her" (Reed, 1989, p. 213).

In the early days, Catherine's new civilized life seems authentically heavenly. In a speech with Nelly in chapter nine, Catherine associates Edgar with peace and comfort, declaring,

I shall like to be the greatest woman of the neighbourhood, and I shall be proud of having such a husband. [....] I love the ground under his feet, and the air over his head, and everything he 
touches, and every word he says - I love all his looks, and all his actions, and him entirely, and altogether (ch.ix, p. 61).

Catherine marries Edgar and falls into ladyhood. But ironically, the farther she goes the closer she faces the fate she secretly wishes to avoid. The new civilized life exacts a price. Having married to Edgar, Catherine is locked into a social system in which she has to renounce her earlier freedom and restrict her needs. This struggle between social rules and the selfish fulfillment of individual impulses, in Freudian psychoanalysis, is a source of the individual's discontents with civilization.

Catherine's renunciation of her unauthorized needs sparks off "seasons of gloom and silence" (ch.x, p. 72). In the civilized world of Thrushcross Grange, she is held fast in the jaws of culture, gentility and education. The Universe has now turned into a "mighty stranger", and she has become "tired of being enclosed here" (ch.xv, p. 125). Her response is a lapse into "malaise that clearly becomes intolerable [and has] wide repercussions" (Reed, 1989, p. 218). Catherine falls into depression and rapidly passes through the stages of mental and physical decay. At this point, she desires a return to her previous state of free and "hardy" girlhood. In chapter twelve of the novel, Catherine points to the paradoxical ramifications of civilization and exclaims,

Oh, I'm burning! I wish I were out of doors-I wish I were a girl again, half savage, and hardy, and free; and laughing at injuries, not maddening under them! Why am I so changed? why does my blood rush into a hell of tumult at a few words? I'm sure I should be myself were I once among the heather on those hills. Open the window again wide, fasten it open! Quick, why don't you move? (ch.xii, p. 98).

Noteworthy, too, in similar ways are the symbolic connotations of the window in the foregoing extract. In "The Window Figure and the Two-Children Figure in Wuthering Heights" (1952), Dorothy Van Ghent shows that the window is a medium, "treacherously transparent, separating the 'inside' from the 'outside', the 'human' from the alien and terrible 'other' ", the civilized from the savage and finally the culture from the nature (pp. 190-1). Ghent claims that Emily Brontë parodies the limitations of civilized life when Catherine, finding herself doomed in the pseudo-heavenly culture of Thrushcross Grange, longs for a "movement to get 'outside"'. Ghent interprets this yearning as Catherine's desire to "break through the limitations of civilized life and of personal consciousness" (p. 197).

\section{Conclusion}

The diversity of opinions and reactions during the century after the publication of Wuthering Heights proves how the novel in the first place advocates interpretations of widely varying emphasis and in the second place calls forth much more commentary. In the following years of its publication in 1847 , each critic attempts to bring something to light by taking one element in the novel and extrapolating it to a total explanation. But, what is noticeable in such an attempt to present a rational explanation of the text is the lack of a study of the roots of such elements based on Freudian psychoanalysis. Moreover, many of these critics have failed to note the influence of the unconscious on the creative work and accordingly have been unsuccessful to link such analysis to Emily' personal life. In effect, we are arguing for connecting the manifest content of the novel to the author's personal life in order to find a truer meaning and interpretation of certain repeated patterns of the novel.

From the arguments put forward in the above paragraphs it is easy to deduce that the existing tension between the inhibiting reality of civilization and the unrestricted reality of nature in Wuthering Heights is in the same way intended as a caricature of genteel and cultured life. Nevertheless, it is partly through Catherine's experience of a new civilized life in Thrushcross Grange that we may come to realize that whatever the benefits of civilization-which is intrinsically and necessarily patriarchal in nature - may be, the limitations imposed on its citizens are not at all welcomed. Through Catherine's symbolic fall, not into heaven, but into hell-i.e. from Wuthering Heights to Thrushcross Grange-and through her strong feelings of nostalgia for a lost freedom and happiness, Emily Brontë calls into question the values of patriarchal culture and its code of conduct.

\section{References}

Dunn, R.J. ed. (2003). A Norton Critical Edition: Emily Brontë Wuthering Heights. $4^{\text {th }}$ ed. New York: W.W. Norton.

Freud, S. (1913a). "Totem and Taboo, Some Points of Agreement between the Mental Lives of Savages and Neurotics". The Standard Edition of the Complete Psychological Works of Sigmund Freud. Trans. James Strachey. 24 vols. London: Hogarth, 1953-74.

... (1930b). "Civilization and Its Discontents". The Standard Edition of the Complete Psychological Works of Sigmund Freud. Trans. James Strachey. 24 vols. London: Hogarth, 1953-74.

... (1931c). "Female Sexuality". The Standard Edition of the Complete Psychological Works of Sigmund Freud. Trans. James Strachey. 24 vols. London: Hogarth, 1953-74.

Ghent, D.v. "The Window Figure and the Two-Children Figure in 'Wuthering Heights'." Nineteenth-Century Fiction, Vol. 7, No. 3 (Dec., 1952), pp. 189-197. JSTO 30 October 2010. <http://www.jstor.org/stable/3044358>

Gold, L. (Mar., 1985) "Catherine Earnshaw: Mother and Daughter". The English Journal, Vol. 74, No. 3, pp. 68-73. JSTOR 30 October 2010. <http://www.jstor. org/stable/817114> 
Gubar, S. "Looking Oppositely: Emily Brontë's Bible of Hell". (1979). A Norton Critical Edition: Emily Brontë Wuthering Heights. Ed. Richard J. Dunn. $4^{\text {th }}$ ed. New York: W.W. Norton, 2003.

Homans, M. (Jan., 1978). "Repression and Sublimation of Nature in Wuthering Heights". PMLA, Vol. 93,No. 1, pp. 919. JSTOR 12 May 2007. <http://www.jstor.org/ stable/00308129>

Hughes, K. (May 2006). "The Freedom of the Soulful Self: An Examination of the Tension Between the Self and Society within Wuthering Heights".<http://www.eastern.edu/academic/cas/depts/english/PDF/writing/Kelly>

Inman, L. (November 2008). "The Awful event in Wuthering Heights". Brontë Studies, Vol. 33.

Pourya A., M. (2014). "Recurring Patterns: Emily Brontë's Neurosis in Wuthering Heights". International Journal of Education and Literary Studies. Vol.2. No.1. <http://www.journals.aiac.org.au/index.php/IJELS /article/view/226/215>

Reed, D. K. "The Discontents of Civilization in Wuthering Heights and Buddenbrooks." Comparative Literature, Vol. 41, No. 3 (Summer, 1989), pp. 209-229. JSTOR 30 October 2010. <http://www.jstor.org/stable/1771107>

Winnifrith, T. (1996). Charlotte and Emily Brontë: A Study in the Rise and Fall of Literary Reputations. The Yearbook of English Studies, Vol. 26, Strategies of Reading: Dickens and after Special Number. pp. 14-24. JSTOR 3 August 2007.<http://www.jstor.org/stable/03062473> 